\title{
RED CELL ENZYME ANOMALIES
}

\author{
Shiro Miwa \\ Department of Pathological Pharmacology, Institute of Medical Science, \\ University of Tokyo, Tokyo 108, Japan
}

\begin{abstract}
Summary Recent advances in the field of red cell enzyme anomalies are reviewed with a stress on G6PD as a genetic marker and on hereditary hemolytic anemia due to red cell enzyme anomalies. Using G6PD as a genetic marker, most benign and malignant tumors have been shown to have a clonal origin, except for neurofibroma and veneral warts which are clearly polyclonal. Recently, the primary structure of human red cell phosphoglycerate kinase was clarified and moreover, single amino acid substitutions of four mutant phosphoglycerate kinases were determined. To accomplish this, a method which requires only $20 \mathrm{ml}$ of blood has been developed. It is a consensus among investigators in this field that the pathogenesis in three-quarters of the congenital nonspherocytic hemolytic anemia patients remain unknown even after adequate red cell enzyme studies which are now available, as well as Carrell's isopropanol test for the detection of unstable hemoglobins.
\end{abstract}

\section{Introduction}

Progress in understanding red cell enzyme anomalies has been rapid in the last two decades owing to the fact that red cells are easy to obtain repeatedly from the patients and that enzymology has advanced a great deal. Since the discovery of glucose 6-phosphate dehydrogenase (G6PD) deficiency in 1956 and pyruvate kinase deficiency in 1961, 16 kinds of red cell enzyme anomalies associated with hereditary hemolytic anemia have been found so far. Moreover, it has become apparent that most, if not all, of the above-mentioned hemolytic anemias were caused by a functionally abnormal enzymes due to structural gene mutation. Single amino acid substitution was proven in a couple of G6PD variants and quite recently, in four mutant phosphoglycerate kinases. Complete amino acid sequence has been obtained in this particular enzyme recently. In this symposium, first I would like to make a brief review of the studies of G6PD as a genetic marker, followed by some recent topics of red cell enzyme anomalies mainly associated with hereditary hemolytic anemia. 


\section{G6PD as genetic marker}

G6PD is inherited as sex-linked character and in addition, is a highly polymorphic enzyme, particularly among black people. About $32 \%$ of black females are heterozygous for G6PD A and B. The fact that only one of the two alleles of a sex-linked gene in a female is expressed is now known as the Lyon hypothesis (Lyon, 1961) or as X-chromosome inactivation. It should be noted that independently Beutler and Baluda (1964) ingeniously demonstrated this phenomenon using human red cell G6PD at about the same time as Lyon who used the mouse to deduce the hypothesis.

Soon after the demonstration that G6PD deficiency was sex-linked (Marks and Gross, 1959) it became apparent that the expression of this defect in heterozygous females is remarkably variable. Although most heterozygotes had about halfnormal G6PD activity, some heterozygotes showed either normal or decreased activity, the latter identical to deficient males. Meanwhile, it should be noted that normal females do not have G6PD activity twice as high as those of the normal males in spite of the existence of two X-chromosomes in females as compared to one in males. Based on the finding by Ohno et al. (1959) that the sex chromatin in rat liver cells is comprised of a single heterochromatic X-chromosome, Beutler reasoned that if only one X-chromosome was active in each cell of a heterozygous G6PD deficiency, two types of red cells, namely, those with normal G6PD activity and those with markedly decreased activity should be produced. Beutler and Baluda (1964) treated with sodium nitrite the red cells obtained from a patient with sickle cell anemia associated with proven heterozygosity for G6PD deficiency showing about half-normal enzyme activity, then incubated the cells with glucose and nile blue, followed by filtration by millipore filter under low oxygen pressure. They then determined G6PD activity of the filtrated red cells. Sodium nitrite converts oxyhemoglobin into methemoglobin whereas glucose and nile blue changes methemoglobin into oxyhemoglobin provided sufficient G6PD, which could supply NADPH required for methemoglobin reduction, is present in the red cell. Red cells which contain the oxy-form of $\mathrm{Hb} \mathrm{S}$ will sickle when oxygen pressure is lowered but the met-form of $\mathrm{Hb} \mathrm{S}$ does not sickle and hence can pass through the millipore filter while in the sickled red cells, they are more rigid and cannot pass through the filter. Filtrated red cells were shown to have markedly decreased G6PD activity equivalent to that of a hemizygous G6PD deficient male, thus clearly confirming the hypothesis that the heterozygous female had two red cell populations.

G6PD has recently been used as a marker for the study of the clonal origin of tumors. If a tumor arises from a single cell, the entire neoplasm should have the same X-chromosome, whereas if a tumor derives from multiple cells, two phenotypes should occur in the tumor. The first application of the G6PD system for the study of tumorigenesis was made of benign neoplasms of the uterine wall, namely, leiomyomas (Gartler and Linder, 1964). As mentioned above, about $32 \%$ of black female would be heterozygous for G6PD A and B. The findings that leiomyomas 
removed from heterozygous females showed only a single G6PD phenotype strongly suggested that a uterine leiomyoma derived from a single cell. Application of this technique to both benign and malignant tumors as well as other diseases has been quite rewarding. Many neoplasma have been investigated, primarily by Fialkow (1976). Their main results are shown in Table 1. Many malignant and many benigh tumors have been shown to be monoclonal in origin. The examples are chronic myelocytic leukemia, polycythemia vera, paroxysmal nocturnal hemoglobinuria, Burkitt lymphoma, common wart, solitary thyroid adenoma, leiomyoma of uterus, lipoma and ovarian teratoma. On the other hand, it is interesting to note that neurofibroma and veneral wart are clearly shown to have derived from multiple cells. Although not shown in the table, quite a interesting finding is the apparent clonal nature of atherosclerotic plaques (Benditt and Benditt, 1973).

Table 1. Single or multiple origin of tumors determined with G6PD marker (Fialkow, 1976).

\begin{tabular}{|c|c|c|}
\hline & \multicolumn{2}{|c|}{ (number of specimens) } \\
\hline \multicolumn{3}{|l|}{ Myeloproliferative disorders } \\
\hline Chronic myelocytic leukemia & 8 & 0 \\
\hline Polycythemia vera & 2 & 0 \\
\hline Paroxysmal nocturnal hemoglobinuria & 2 & 0 \\
\hline \multicolumn{3}{|l|}{ Lymphoproliferative disorders } \\
\hline Burkitt lymphoma & 45 & 1 \\
\hline \multicolumn{3}{|l|}{ Carcinoma } \\
\hline Nasopharynx (anaplastic) & 7 & 0 \\
\hline Cervix, pre-invasive & 9 & 0 \\
\hline invasive & 8 & $2(?)^{a}$ \\
\hline Thyroid & 5 & 0 \\
\hline \multicolumn{3}{|l|}{ Hereditary } \\
\hline Neurofibroma & 0 & 14 \\
\hline \multicolumn{3}{|l|}{ Viral } \\
\hline Common wart & 6 & 0 \\
\hline Veneral wart & 0 & 4 \\
\hline \multicolumn{3}{|l|}{ Endocrine } \\
\hline Solitary thyroid adenoma & 22 & 0 \\
\hline \multicolumn{3}{|l|}{ Miscellaneous benign } \\
\hline Leiomyoma uterii & 184 & 0 \\
\hline Lipoma & 6 & 0 \\
\hline Ovarian teratoma & 39 & 0 \\
\hline
\end{tabular}

a Contamination by normal tissue possible. 
Herreditary hemolytic anemia due to red cell enzyme anomalies

A list of red cell enzyme defects which cause hereditary hemolytic anemia is shown in Table 2 (Beutler, 1978; Miwa, 1979). Although almost all the red cell enzyme anomalies associated with hemolytic anemia show decreased enzyme activity, it is worth noting that cases of increased red cell adenosine deaminase activity associated with hereditary hemolytic anemia are cuased by 40- to 70-fold increases in enzyme activity, showing autosomal dominant inheritance. A deficiency of this particular enzyme, resulting from the production of a structurally abnormal enzyme, causes a severe combined immunodeficiency showing autosomal recessive inheritance. It is most likely though not definitely proven, that the overproduction of the enzyme by a regulatory gene mutation (Fujii et al., 1980a). Recently we investigated the mechanism of red cell adenosine deaminase accumulation in a case with this disorder (Fujii et al., 1982). Adenosine deaminase activity of the younger cells of the patient was higher than that of the older cells, indicating that the increased number of the enzyme molecules was not subject to prolonged decay of the enzyme. The rate of adenosine deaminase synthesis in erythroid colony cells cultured from the patient's bone marrow cells was 11 -fold greater than that of normal. The ac-

Table 2. List of red cell enzyme anomalies that cause hereditary hemolytic anemia.

\begin{tabular}{ll}
\hline Red cell enzyme anomalies & Mode of inheritance \\
\hline $\begin{array}{l}\text { Enzyme of glycolytic pathway } \\
\text { Hexokinase deficiency } \\
\text { Glucosephosphate isomerase deficiency } \\
\text { Phosphofructokinase deficiency }\end{array}$ & Autosomal recessive \\
$\begin{array}{l}\text { Aldolase deficiency } \\
\text { Triosephosphate isomerase deficiency }\end{array}$ & Autosomal recessive \\
$\begin{array}{l}\text { Phosphoglycerate kinase deficiency } \\
\text { Pyruvate kinase deficiency }\end{array}$ & Autosomal recessive \\
Rapoport-Luebering cycle & Autosomal recessive \\
Diphosphoglyzerate mutase deficiency & Autosomal recessive \\
Hexosemonophosphate pathway and glutathione metabolism & Sex-linked \\
$\begin{array}{l}\text { Glucose 6-phosphate dehydrogenase deficiency } \\
\text { Glutathione reductase deficiency }\end{array}$ & Autosomal recessive \\
$\begin{array}{l}\text { Glutathione peroxidase deficiency } \\
\text { Glutathione synthetase deficiency }\end{array}$ & Autosomal recessive \\
$\gamma$-Glutamyl-cysteine synthetase deficiency & Sex-linked \\
Nucleotide metabolism & Autosomal recessive \\
$\begin{array}{l}\text { Adenylate kinase deficiency } \\
\text { Pyrimidine 5'-nucleotidase deficiency } \\
\text { Adenosine deaminase overproduction }\end{array}$ & Autosomal \\
\hline
\end{tabular}


cumulation of adenosine deaminase in the patient seems to be due to increased synthesis of the enzyme in red cell precursors.

Red cell enzyme anomalies associated with hereditary hemolytic anemia usually do not show any characteristic abnormality in red cell morphology, except for pyrimidine 5 '-nucleotidase deficiency which shows remarkably basophilic stippling of the red cell (Miwa, 1980). Hence, these anemias are included in so-called congenital nonspherocytic hemolytic anemias.

Regarding to the procedures for red cell enzyme assays, an expert panel on red cell enzyme of the Internal Committee for Standardization in Haematology (ICSH) published recommended methods (Beutler et al., 1977).

It has become increasingly apparent that most, if not all, of the enzyme deficiencies associated with hereditary hemolytic anemia are caused by a structural gene mutation, resulting in production of a mutant enzyme which has either defective enzyme function, instability of the enzyme molecules, or a combination of both. Unstable enzymes exert a profound effect on mature red cells because they are unable to synthesize new enzyme protein molecules due to the lack of ribosomes whereas other tissues can. Therefore an unstable enzyme, such as mutant glucosephosphate isomerase, which is distributed in all tissues, causes a shortend red cell lifespan (hemolytic anemia) but does not result in clinical manifestation in other tissues.

As mentioned above, in most cases, enzyme deficiencies are caused by a structural gene mutation. Thus one particular enzyme deficiency can have many genetic variants, similar to the existence of hundreds of abnormal hemoglobins. For example, in G6PD deficiency over 150 variants have been identified according to the procedure for characterizing G6PD variants recommended by the WHO working group (1967). Recently, recommended methods for characterizing pyruvate kinase variants have been published by the ICSH (Miwa et al., 1979), and more than seven variants have been established by these methods (Miwa et al., 1980; Shinohara and Tanaka, 1980). It should be emphasized that among certain enzyme anomalies associated with hereditary hemolytic anemia, the activity determined by a conventional assay procedure may show normal or even higher than normal values (Miwa, 1981). This rather confusing situation results from the difference in substrate concentrations between in vivo and in vitro conditions. In the latter, considerably higher substrate concentrations as compared to those in vivo are ordinarily used, and a high $K_{\mathrm{m}}$ for phosphoenolpyruvate variants may show normal enzyme activity. There are two approaches to avoid this possibility. One is to use considerably less substrate in the reaction mixture than that used in the conventional assay. The other method is to determine glycolytic intermediates and search for an accumulation above the defective step of glycolysis. For example, in pyruvate kinase deficiency, red cell phosphoenolypyruvate, 2-phosphoglycerate, 3-phosphoglycerate and 2,3-diphosphoglycerate are regularly found to be increased.

Although Yoshida reported single amino acid substitutions for two G6PD 
variants (Yoshida, 1967; 1970), the primary [structure of all the enzymes which could cause hemolytic anemia had not been determined until recently. In 1980, Yoshida and his colleagues succeeded in determining the primary structure of normal human red cell phosphoglycerate kinase (PGK) (Huang et al., 1980). In addition, they were able to determine the single amino acid substitution for four mutant red cell PGKs, namely, PGK II, PGK Munchen, PGK Uppsala and PGK Tokyo (Fujii et al., 1980b, 1980c, 1981). In order to determine the amino acid substitution, $500 \mathrm{ml}$ of patients' blood was required except for PGK Tokyo, for which only $18 \mathrm{ml}$ of the patient's blood was required because the investigators developed a quite ingenious method (Fujii et al., 1981). They separated lymphocytes from the blood and incubated the lymphocytes with EB-virus, cultured the transformed lymphoblastoid cell, and then purified the mutant enzyme from the cultured lymphoblastoid cells.

Since the tertiary structure of horse muscle PGK was determined by Bank et al. by X-ray crystallographic studies and as only 14 amino acids out of 417 are different between horse and human PGK, the three-dimensional structure of human PGK is inferred to be almost identical to that of the horse enzyme. Yoshida et al. analyzed the structure and functional relationship of mutant human red cell PGKs and showed how PGK Tokyo and PGK Uppsala caused moderate hemolytic anemia whereas PGK II did not cause clinical manifestations.

These studies performed by Yoshida and his colleagues on PGK are really the topic of the day. It is important for us to realize from these studies that certain

Table 3. Occurrence of red cell enzyme anomalies in previously undiagnosed cases with congenital nonspherocytic hemolytic anemia studied in our laboratory from 1972 to 1980 .

\begin{tabular}{lc} 
& Number of cases \\
\hline Red cell enzyme anomalies & 88 \\
Glucosephosphate isomerase deficiency & 7 \\
Phosphofructokinase deficiency & 2 \\
Aldolase deficiency & 2 \\
Phosphoglycerate kinase deficiency & 1 \\
Pyruvate kinase deficiency & 43 \\
Glucose 6-phosphate dehydrogenase deficiency & 25 \\
Glutathione peroxidase deficiency & 1 \\
Pyrimidine 5'-nucleotidase deficiency & 6 \\
Adenosine deaminase deficiency & 1 \\
Unstable hemoglobin hemolytic anemia & 10 \\
Congenital nonspherocytic hemolytic anemia of unknown etiology & 156 \\
\hline Total & 254 \\
\hline
\end{tabular}


Table 4. Hereditary nonhematologic disorders that can be diagnosed by determination of red cell enzyme activity.

\begin{tabular}{|c|c|c|}
\hline Diseases & Deficient enzymes & Mode of inheritance \\
\hline Acatalasemia & Catalase & Autosomal recessive \\
\hline Lesch-Nyhan syndrome & $\begin{array}{l}\text { Hypoxanthine guanine } \\
\text { phosphoribosyltransferase }\end{array}$ & Sex-linked \\
\hline Galactosemia & $\begin{array}{l}\text { Galactose 1-phosphate } \\
\text { uridyltransferase or galactokinase a }\end{array}$ & Autosomal recessive \\
\hline Severe combined immunodeficiency & Adenosine deaminase & Autosomal recessive \\
\hline $\begin{array}{l}\text { Immunodeficiency (defective } \\
\text { T-cell immunity) }\end{array}$ & Purine nucleoside phosphorylase & Autosomal recessive \\
\hline Renal tubular acidosis & Carbonic anhydrase-I & Autosomal recessive \\
\hline Hereditary methemoglobinemia & $\begin{array}{l}\text { NADH-methemoglobin reductase } \\
\text { (NADH diaphorase, cytochrome } \\
b_{5} \text { reductase) }\end{array}$ & Autosomal recessive \\
\hline
\end{tabular}

a Sometimes it is necessary to assay uridine diphosphate galactose 4-epimerase in order to exclude galactosemia.

red cell enzyme anomalies, at least mutant PGKs, could be studied at the molecular level, as in the case of hemoglobinopathies. Based on these studies, future rapid advances in the field of red cell enzyme anomalies is expected.

It is the consensus of investigators in this field that the pathogenesis in threequarters of the congenital nonspherocytic hemolytic anemia patients remains unknown even after adequate red cell studies, as well as Carrell's isopropanol test for unstable hemoglobins have been done (Beutler et al., 1980). The results of our study are similar and are shown in Table 3. Therefore, it is necessary to perform more detailed enzyme assays using both conventional and low substrate systems as well as to assay for red cell glycolytic intermediates and adenine nucleotides so as to avoid overlooking enzyme anomalies. Efforts to discover new enzyme anomalies should also be made.

Red cell enzyme assays for the diagnosis of congenital nonhematologic disorders

It is possible to diagnose nonhematologic heritable diseases by simply measuring red cell enzyme activities, provided that the enzyme of the red ceil and of the target organ(s) demonstrating abnormal functions are under the control of the same structural gene (Miwa, 1979). Such diseases and the defective enzymes involved are listed in Table 4. In this table, hereditary methemoglobinemia which is a hematologic disorder is also included for convenience.

Acknowledgements A part of our studies presented here was granted from The Ministry of Education, Science and Culture, and The Ministry of Health and Welfare, Japan. 


\section{REFERENCES}

Benditt, E.P., and Benditt, J.M. 1973. Evidence for a monoclonal origin of human atherosclerotic plaques. Proc. Natl. Acad. Sci. USA. 70: 1753-1756.

Beutler, E., and Baluda, M.C. 1964. The separation of glucose-6-phosphate-dehydrogenase-deficient erythrocytes from the blood of heterozygotes for glucose-6-phosphate-dehydrogenasedeficiency. Lancet 1: 189-192.

Beutler, E., Blume, K.G., Kaplan, J.C., Loehr, G.W., Ramot, B., and Valentine, W.N. 1977. International Committee for Standardization in Haematology: Recommended methods for redcell enzyme analysis. Brit J. Haemat. 35: 331-340.

Beutler, E. 1978. Hemolytic Anemia in Disorders of Red Cell Metabolism. Plenum, New York.

Beutler, E., Bonaventura, C., Huisman, T.H.J., Minakami, S., Miwa, S., Nakao, M., Schneider, R.G., Schroeder, W.A., Tanaka, K.R., Tashian, R.E., Valentine, W.N., and Yoshida, A. 1980. Round Table: Enzymatic deficiencies of the red cell. Homoglobin 4: 805--819.

Fialkow, F.J. 1976. Clonal origin of human tumors. Biochim. Biophys. Acta 458: 283-321.

Fujii, H., Miwa, S., and Suzuki, K. 1980a. Purification and properties of adenosine deaminase in normal and hereditary hemolytic anemia with increased red cell activity. Hemoglobin 4: 693-705.

Fujii, H., Krietch, W.K.G., and Yoshida, A. 1980b. A single amino acid substitution (Asp-Asn) in a phosphoglycerate kinase variant (PGK München) associated with enzyme deficiency. J. Biol. Chem. 255: 6421-6423.

Fujii, H., and Yoshida, A. 1980c. Molecular abnormality of phosphoglycerate kinase-Uppsala associated with chronic nonspherocytic hemolytic anemia. Proc. Natl. Acad. Sci. USA. 77: $5461-5465$.

Fujii, H., Chen, S-H., Akatsuka, J., Miwa, S., and Yoshida, A. 1981. Use of cultured lymphoblastoid cells for the study of abnormal enzymes: Molecular abnormality of a phosphoglycerate kinase variant associated with hemolytic anemia. Proc. Natl. Acad. Sci. USA. 78: 2587-2590.

Fujii, H., Miwa, S., Tani, K., Fujinami, N., and Asano, H. 1982. Overproduction of structurally normal enzyme in man: Hereditary haemolytic anaemia with increased red cell adenosine deaminase activity. Brit. J. Haemat. (in press).

Gartler, S.M., and Linder, D. 1964. Developmental and evolutionary implications of the mosaic nature of the G-6-PD system, Cold Spring Harbor Symp. Quant. Biol. 29: 253-260.

Huang, I-Y., Welch, C.D., and Yoshida, A. 1980. Complete amino acid sequence of human phosphoglycerate kinase. J. Biol. Chem. 255: 6412-6420.

Lyon, M.F. 1961. Gene action in the X-chromosome of the mouse (Mus musculus). Nature (London) 190: 372-373.

Marks, P.A., and Gross, R.T. 1959. Further characterization of the enzymatic defect in erythrocyte glucose-6-phosphate dehydrogenase deficiency. A genetically determined trait. J. Clin. Invest. 38: 1023-1024.

Miwa, S. 1979. Significance of the determination of red cell enzyme activities. Am. J. Hemat. 6: $163-172$.

Miwa, S., Boivin, P., Blume, K.G., Arnold, H., Black, J.A., Kahn, A., Staal, G.E.J., Nakashima, K., Tanaka, K.R., Paglia, D.E., Valentine, W.N., Yoshida, A., and Beutler, E. 1979. International Committee for Standardization in Haematology: Recommended methods for the characterization of red cell pyruvate kinase variants. Brit. J. Haemat. 43: 275-286.

Miwa, S. 1980. Clinical and biochemical studies on mutant red cell enzymes mainly associated with hemolytic anemia. Jpn. J. Human Genet. 25: 83-92.

Miwa, S., Fujii, H., Takegawa, S., Nakatsuji, T., Yamato, K., Ishida, Y., and Ninomiya, N. 1980. Seven pyruvate kinase variants characterized by the ICSH recommended methods. Brit. J. 
Haemat. 45: 575-583.

Miwa, S. 1981. Pyruvate kinase deficiency and other enzymopathies of the Embden-Meyerhof pathway. Clin. Haemat. 10: 57-80.

Ohno, S., Kaplan, W.D., and Kinoshita, R. 1959. Formation of the sex chromatin by a single Xchromosome in liver cells of Rattus norvegicus. Exp. Cell Res. 18: 415-418.

Shinohara, K., and Tanaka, K.R. 1980. Pyruvate kinase deficiency hemolytic anemia: Enzymatic characterization studies in twelve patients. Hemoglobin 4: 611-625.

WHO Scientific Group 1967. Standardization of procedures for the study of glucose-6-phosphate dehydrogenase. WHO Tech. Rep. Ser. 366: 1-53.

Yoshida, A. 1967. A single amino acid substitution-asparagine to aspartic acid--between normal $(\mathrm{B}+)$ and the common Negro variant $(\mathrm{A}+)$ of human glucose-6-phosphate dehydrogenase. Proc. Natl. Acad. Sci. USA. 57: 835-840.

Yoshida, A. 1970. Amino acid substitution (histidine to tyrosine) in a glucose-6-phosphate dehydrogenase variant (G6PD Hektoen) associated with over-production. J. Mol. Biol. 52: 483490. 